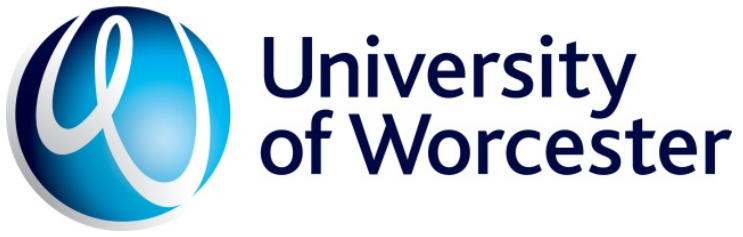

Original citation: Newland, Paul (2016) The Spatial Politics of the Voice in Patrick Keiller's Robinson in Ruins (2010). The New Soundtrack, 6 (2). pp. 129-142. ISSN Print: 2042-8855 Online: 2042-8863

Permanent WRaP URL: https://eprints.worc.ac.uk/id/eprint/9220

\section{Copyright and reuse:}

The Worcester Research and Publications (WRaP) makes this work available open access under the following conditions. Copyright $\odot$ and all moral rights to the version of the paper presented here belong to the individual author(s) and/or other copyright owners. To the extent reasonable and practicable the material made available in WRaP has been checked for eligibility before being made available.

Copies of full items can be used for personal research or study, educational, or not-for-profit purposes without prior permission or charge, provided that the authors, title and full bibliographic details are credited, a hyperlink and/or URL is given for the original metadata page and the content is not changed in any way.

Publisher's statement: This is an Accepted Manuscript of an article published by Edinburgh University Press in The New Soundtrack, available online: https://www.euppublishing.com/doi/10.3366/sound.2016.0087

\section{A note on versions:}

The version presented here may differ from the published version or, version of record, if you wish to cite this item you are advised to consult the publisher's version. Please see the 'permanent WRaP URL' above for details on accessing the published version and note that access may require a subscription.

For more information, please contact wrapteam@worc.ac.uk 
NS6.2_art_newland/sd.14.04.16:pn14.04.16;sd17.04.16

\title{
The Spatial Politics of the Voice in Patrick Keiller's Robinson in Ruins (2010) Paul Newland
}

\begin{abstract}
This article engages with the ways in which Vanessa Redgrave's voice-over operates in spatial terms in Patrick Keiller's film Robinson in Ruins. It argues that through a combination of omniscient authority, self-reflexive irony, and the mannered vocal performance of the role of a fictional character, Redgrave's voice-over ultimately evokes an uncontainable presence. Writers such as Michel Chion and Mary Ann Doane have considered film voice-overs as 'disembodied' phenomena, but the paper demonstrates that the fluid play of presence and absence in Redgrave's disembodied voice-over in Robinson in Ruins - but also the grain of this voice, its performative qualities, and its evident display of traces of an enduring star persona-informs, in very complex ways, the free and open concept of place and spatiality that the film explores and articulates. Through its recounting of Robinson's story, its setting out of innumerable historical facts, and its focus on off-screen as well as on-screen images, Redgrave's fluid voice-over constructs a complex, highly politicized sound territory; a shifting sonic space referred to below as a phonotope. By exploring this example in detail one can show how we might benefit from paying attention to the spatial properties of voices on film, by drawing, in particular, on insights drawn from cultural geography.
\end{abstract}

\section{Keywords}

Voice

Voice over

Voice off

Space

Place

Spatiality

Patrick Keiller

Robinson in Ruins

Vanessa Redgrave 


\section{Doreen Massey}

An architect's eye defines Patrick Keiller's films. The director studied at the Bartlett School of Architecture and at University College, London, has worked as a practising architect, and has taught architecture as well as fine art (Dave 2000: 340). London (1993), Robinson in Space (1997) and Robinson in Ruins (2010) are predominately characterised almost exclusively by static camera shots of buildings and landscapes. But sound - and especially the off-screen voice - has also come to perform a crucial role in the development of Keiller's idiosyncratic filmmaking style. Indeed, the voiceovers provided by unseen speakers are key to the structural aesthetic of his films, as well as to the successful communication of their politically charged messages.

The narrators Paul Scofield (in London and Robinson in Space) and Vanessa Redgrave (in Robinson in Ruins) present highly complex performances. They essentially function as quasi-omniscient documentary voice-overs, reporting on the eccentric activities of an unseen, fictional character, Robinson, a poetic itinerant seemingly obsessed with uncovering buried narratives in otherwise drab, uncelebrated British locations. But these voices are never straightforwardly omniscient, and as such they serve ironically to challenge traditional documentary filmmaking orthodoxies, especially through the regular injection of humour and a barbed sense of irony (see Smith 2000: 149). Beyond telling Robinson's story, these voices also serve to interpret some (but by no means all) of the images of places that Keiller's camera captures, commenting on them, placing them within historical, economic, topographical and architectural contexts, and suggesting previously unnoticed or unseen connections between these places and the various objects depicted therein. Moreover, in their lengthy propounding of factual information and densely detailed historical narratives, these voices often depart from commenting on the specific images shown. Iain Sinclair has suggested that in London and Robinson in Space, Paul Scofield serves as a 'distancing device' (Sinclair 1994: 13). But this article argues that the voices in all three films construct their own crucial spatiality in which the places and objects captured by the camera are brought into politically charged dialogue with other, imagined, off-screen places, objects, individuals, communities, historical narratives and political discourses. That is, in these films, the voices of the narrators become highly complex and political spatial phenomena. 
This article engages specifically with the ways in which Vanessa Redgrave's voice-over operates in spatial terms in the third film in the series, Robinson in Ruins. It argues that through a combination of omniscient authority, self-reflexive irony, and the mannered vocal performance of the role of a fictional character, Redgrave's voice-over ultimately evokes an uncontainable presence. Writers such as Michel Chion and Mary Ann Doane have considered film voice-overs as 'disembodied' phenomena, but one can observe that the fluid play of presence and absence in Redgrave's disembodied voice-over in Robinson in Ruins - as well as the grain of this voice, its performative qualities, and its evident display of traces of an enduring star persona - informs, in very complex ways, the free and open concept of place and spatiality that the film explores and articulates. ${ }^{1}$ Through its recounting of Robinson's story, its customary setting out of innumerable historical facts, and its focus on offscreen as well as on-screen images, Redgrave's fluid voice-over constructs a complex, highly politicized sound territory; a shifting sonic space referred to below as a phonotope. By exploring this example in detail this article demonstrates how we might benefit from paying attention to the spatial properties of voices on film, by drawing, in particular, on insights drawn from cultural geography.

In Robinson in Ruins the unseen, titular Robinson embarks upon a series of walks around rural Oxfordshire and Berkshire in order to address 'problems' linked to what he sees as a contemporary socio-cultural, economic and ecological malaise. As Vanessa Redgrave's narrator explains in a curiously mannered way at the beginning of the film, 'He believed that he could communicate with a network on non-human intelligences that had sought refuge in marginal and hidden locations. They were determined to preserve the possibility of life's survival on the planet, and enlisted him to work on their behalf.' Redgrave's narrator further explains that Robinson 'was equipped with an ancient cine camera with which he made images of his everyday surroundings.' Here, as elsewhere in the film, Redgrave's performed voice-over resists easy classification, for several reasons: one, because of the mixture of documentary fact and surreal commentary offered by the narration (scripted by Keiller) itself; two, because her performance moves fluidly between seeming omniscience on the one hand and a knowing, ironic performance of the role of a fictional character (the co-founder of a research institution with which the fictional Robinson seemingly had links) on the other; and, three, because the voice of a star 
(and thus a recognisable star persona) is in play to varying degrees throughout. This fluidity of vocal performance actively serves to elucidate, in aesthetic terms, the politically charged messages of the film.

On his meandering walks, Robinson constantly finds his routes barred by fences and barriers which demonstrate the ownership and control of this land by global corporations, the state, and the US military. Indeed, the film demonstrates that free movement through this contemporary landscape is never easy, and that these are not places that one can dwell in in any simple, straightforward or indeed traditional way. Through Robinson's often curtailed wandering, Robinson in Ruins suggests that neoliberal globalisation and the concomitant control and closing off of places has brought about a profound sense of displacement, and asks, in relation to this area in southern England, what might an individual's current relationship to a distinct place be? The film is thus at pains to emphasize how far this southern English landscape is in effect just another space within a contemporary global network of power, capital and labour. It has effectively been 'enclosed'; that is, taken away from the material or imaginative ownership of common people. But the film also suggests - through the aesthetic function of Redgrave's performed voice-over, especially - that such enclosure of a landscape might be resisted. Indeed, as it does this, the film demonstrates that what we are seeing is in fact a landscape that has a long history of being identified with enclosure and subsequent resistance to such enclosure.

The Enclosure (Inclosure) Acts in England (in the late-eighteenth and earlynineteenth centuries) ended traditional rights to mow meadows for hay or graze animals on commons. Open fields were gradually fenced, deeded and titled to landowners. This led to the subsequent displacement of individuals, families and communities. Redgrave's narrator tells of how Robinson recognised the legacy of these events. For example, over images of a large green road sign at the Kennington Roundabout on the Oxford bypass - first a medium shot and then extreme close-ups, showing lichen growing on the edges of the letters in the word 'Newbury' Redgrave's narrator remarks:

He had read that one of the factors that enabled industrial capitalism to develop first in England was the mobility of the previously settled agricultural workforce. Such labour market 
flexibility however derived not from any Anglo-Saxon customary freedoms, but from Government legislation: an act to prevent the removal of poor persons until that could become chargeable: the 1795 amendment to the Settlement Act.

Redgrave's narrator similarly notes that on his travels Robinson became interested the Speenhamland System, a form of relief inaugurated by Berkshire magistrates which aimed to alleviate rural poverty in eighteenth-century England. In his research for the film, Keiller noticed that 1795 (the year in which the Speenhamland System was introduced) was also the year in which the 1662 Settlement Act was amended to enable 'hands to go where burgeoning capitalist enterprise needed them most' (Keiller 2009). By focusing on places situated close to where this system was inaugurated, the film thus presents Speenhamland as an important historical narrative in the development of modern Britain that resonates powerfully today, precisely because it was an attempt to counter the economic suffering of labourers and their forced migration. Robinson in Ruins becomes preoccupied with the notion of spatial enclosure, and methods of resistance to this enclosure, through its focus on Speenhamland, the 1662 Settlement Act,, and its uncovering of links between this historical narrative, protests at Otmoor in the 1830s, as well as nuclear protestors at Aldermaston and Greenham. In order to aesthetically counter such enclosure, Redgrave's voice-over develops a fluid, unbounded spatiality, or 'phonotope'.

\section{Phonotopes}

The phonotope (the prefix 'phono' deriving from the Greek work for 'sound', but also suggesting 'speech' or 'voice') can be best understood as an audio-visual redevelopment of Mikhail Bakhtin's notion of the literary chronotope, specifically pertaining to the potentially spatial effects and functions of the human voice. For Bakhtin, a chronotope is a 'time-space'. (Bakhtin 1981: 84) Bakhtin was concerned with how the literary form of the novel produces chronotopes, writing that 'every literary image is chronotopic' (Bakhtin 1981: 251). That is, for Bakhtin, all forms of writing contain junctions between space and time. Accordingly, in novels, 'real' historical time and space, and 'imagined' or 'fictional' time and space, are always necessarily articulated in relation to one another, or are, in Bakhtin's terms, in 
dialogue. ${ }^{2}$ His emphasis on the notion of the literary 'image' has led scholars to argue that films might also provide the ideal site for the construction and exploration of chronotopes (Stam 1989). But the theorisation of the ways in which the human voice develops and produces spatiality in film remains underexplored. It is suggested here that the concept of the filmic phonotope might be employed to do this. The phonotope can be best understood as a 'voice-space' which temporally informs and structures the spatial imaginary and, as it does this, transcends material, 'real' spaces represented by the images in a film. In other words, phonotopes are filmic time-spaces in which voices develop a temporal dialogue between 'real' places, places represented in images onscreen, and places that are described by these voices but that remain unseen and off-screen.

With this emphasis on speech and spatiality, the concept of the phonotope notably differs from Jacob Smith's notion of the 'sonotope', which describes the 'intrinsic connectedness of sound and space' (Smith 2008: 245). ${ }^{3}$ Smith offers the example of the concert hall as a sonotope, as it is a space that encourages a particular type of vocal performance. While the phonotope also certainly connects 'sound and space', I see it very much as a geographically spatial phenomenon, not just as a means of describing how a space impacts on sound. Rather, a phonotope might be understood as a conceptual voice/space that can allow a spectator/listener to imagine and subsequently describe specific landscapes or territories suggested by vocal

performances. Because phonotopes can disorganise and reimagine the 'real' and bring spatial fantasy and the everyday reality of specific places into dialectical contact with one another, they can possess political functions. Political potentialities of phonotopes are suggested by Vanessa Redgrave's performance in Robinson in Ruins. ${ }^{4}$

\section{The voice of Vanessa Redgrave}

In the history of British documentary filmmaking, the voice-over has traditionally appeared as an omniscient presence, and has tended to be authoritarian, male and upper middle class (Chanan 2007: 116). For Bill Nichols, in the mode of 'direct address', the male voice-over is 'overwhelmingly didactic' in its domination of the visual (Nichols 1988: 48). Stella Bruzzi employs Laurence Olivier's voice-over in the Thames Television series The World at War as an example of a conventional 'voice of God' documentary voice-over, noting that Olivier's vocal 'sonority' gestures 
towards the strong evidence of the presence of his star persona in this voice. Bruzzi argues that Olivier is essentially 'acting' pre-scripted lines (Bruzzi 2000: 44). But she makes an intriguing point about the evidently masculine tradition of such documentary filmmaking:

The traditional expository mode of direct address relies on proximity between text and image: the words explicate the visuals, telling the spectator how he or she should interpret them; the potential for secondary, connotative meaning is limited. A crucial component of such an 'unproblematic' narration has traditionally been held to be the masculinity of the 'voice of God', the traditional tones of authority and universality. (Bruzzi 2000: 57)

While to a certain extent Paul Scofield's narrations of London and Robinson in Ruins adhere to - but also at the same time subvert - this expository documentary tradition, Vanessa Redgrave's voice in Robinson in Ruins takes the act of subversion further in a range of ways, not least through its gendered identity. After all, Stella Bruzzi has argued that a female commentary is 'an overt tool for exposing the untenability of documentary's belief in its capacity for imparting 'generalised truths' faithfully and unproblematically.' (Bruzzi 2000: 59) Thus, Redgrave's fluid, feminine voice-over might be read as an aesthetic tool that facilitates a kind of spatial 'breaking free': a breaking free from the accepted generic rules of documentary filmmaking, and, as such, breaking free from boundaries per se (just as Keiller wants to free contemporary places from material and imaginative 'enclosure').

Redgrave's performance resists generic categorisation as the voice of a fictional character, but it might be deemed to be an example of a quasi 'voice-off' (a 'voiceoff' being a voice-over provided by a character pictured on screen at least once in a film). ${ }^{5}$ Interestingly, writing about films such as Letter from an Unknown Woman (Ophüls, 1948) which feature voice-offs, Britta Sjogren has argued that 'The female voice-off tends to provide a plurality of points of view within a film text, influencing the textual form of a film in revealing ways.' (Sjogren 2006: 15) While Redgrave does not perform a voice-off per se in Robinson in Ruins (she does perform the role of a fictional character, but this character always remains unseen, off screen), Sjogren's insights might allow us to consider how far Redgrave's performance of the 
voice of an unseen fictional character evokes psychological heterogeneity, primarily because this voice resists simple placement in terms of exteriority and interiority, and thus manages to evoke a range of incompatible perspectives that together serve to facilitate the articulation of a sense of spatial freedom.

There is more to say about the heterogeneous nature of this voice, its potentially incompatible perspectives, and the aesthetic ramifications of this on the development of the phonotope in Robinson in Ruins. Redgrave's voice is an upper-middle-class, actorly female voice. As such it articulates a sense on knowledge and authority, and, as such, it chimes in some ways with the documentary filmmaking tradition mentioned earlier. But it is also a voice that belongs to one individual performer, a very well known star, and a member of a distinguished British acting family. The rich and husky grain (Barthes 1977) of Redgrave's voice, its stately enunciation and liltingly slow rhythms, would no doubt make it very recognisable to wide audiences. Furthermore, this voice bears the weight of age and, therefore, experience. It is, after all, an older incarnation of the voice of Anne Boleyn in Fred Zinnemann's A Man for All Seasons (1966), of Guinevere in Camelot (Joshua Logan, 1967), of Sylvia Pankhurst in Oh! What a Lovely War (Richard Attenborough, 1969), of Ruth Wilcox in Howard's End (James Ivory, 1992), and of Clarissa Dalloway in Mrs Dalloway (Marleen Gorris, 1997). These past performances - often playing characters that contend with and react to masculine power and authority - exist as traces in Redgrave's present performance as the narrator in Robinson in Ruins. That is, her voice carries the weight of these past performances (which are all, it should be said, performances in opposition to power) in its articulation of an opposition to the enclosure and control of places.

It is also important to note that the presence of Redgrave's voice in Robinson in Ruins invokes her identity as a voice of the British Left, and as such evidences residue of her history of political activism (especially with regards to the plight of the Palestinians). ${ }^{6}$ The casting of Redgrave was therefore a pertinent choice for this film's narrator, given that Robinson in Ruins, released just two years after the economic crash of 2008, serves as such a powerful critique of Britain's continued embrace of an evidently destructive neoliberalism. 
While Redgrave's voice-over is key to the articulation of Keiller's political critique, her performance is complicated, and has drawn a varied critical response. For example, in his review essay on Robinson in Ruins in Sight and Sound, Mark Fisher criticises Redgrave's narration, suggesting that 'doesn't quite work', and is 'oddly tentative' (Fisher 2010: 24). Certainly, sometimes the voice does feel strangely unsure of itself, such as during the opening narration: 'When a man called Robinson was released from Edgecote open prison, he made his way to the nearest city, and looked for somewhere to haunt.' Here Redgrave pauses rather uneasily between the words 'open' and 'prison' and the phrase 'somewhere to haunt'. This section of the performance in some ways gives the impression that the script is being read for the first time. But we might instead interpret this as an example of Redgrave potentially measuring out an ironic distance between herself, Redgrave-as-star, the fictional character (researcher) she is playing, and Keiller's dense, fact-laden script. So this is not to say that the narration does not work; rather, it is complicated, and it resists a straightforward critical reading. That is, the voice in Robinson in Ruins cannot be located. Indeed, it is here, in these moments of apparent hesitancy in Redgrave's performance, that any possible sense of omniscience is problematized. As this happens, the film is freed from generic constraints. In other words, these moments of hesitancy might be read as just one characteristic of a fluid performance that serves to resist enclosure (generic or otherwise).

Moments later in the film, however, Redgrave's delivery feels much more comfortable, confident, assured and even knowing, when she speaks the lines: 'For a few weeks he dared go no further than the city's outskirts. He believed he could communicate with a network of non-human intelligences.' In a similar mode of performativity, her voice remarks: 'In the middle of March the banking crisis intensified with the failure of an eleven billion pound Carlyle hedge fund and the near collapse of Bear Stearns, the United States' fifth largest bank.' This sentence is spoken over an image of a boarded-up building, situated alongside a tree in blossom. Because this image is not particularly striking, the spoken words here - as elsewhere in the film - are what primarily hold the attention, and appeal to the imagination. Redgrave certainly performs these words in a rather curious, idiosyncratic way, evidently taking great ironic pleasure in the name 'Bear Stearns', delivering it with a mocking contempt. But then she sounds rather hesitant again with the words 'an 
eleven billion pound Carlyle hedge fund'. This narration is followed by a sentence setting out Robinson's aims thus: 'From a nearby car park he surveyed the centre of the island on which he was shipwrecked, 'the location', he wrote, 'of a great malady that I shall dispel in the manner of Turner by making picturesque views on journeys to sites of scientific and historic interest'. These lines are spoken over an unremarkable, drab image of suburban Oxford, in which no familiar iconography is foregrounded. Again, the words 'centre of the island' here are loaded with irony. So, mixing moments of controlled and forceful enunciation with moments of heavy irony and moments of apparent hesitancy, Redgrave's performance in Robinson in Ruins cannot be yoked to a singular mode of address, documentary or otherwise. It is a heterogeneous performance that ultimately floats free of interiority and exteriority, omniscience, characterisation, star persona, individual expression, and, as such, generic expectation and location.

Contradictory and multi-faceted, then, Redgrave's vocal performance in Robinson in Ruins lends a spatial complexity to the images presented on screen, one that is particularly brought into relief through a disjuncture between this voice, the wider soundscape, and the images. Very often, the voice speaks of places, objects, facts or historical narratives that are not pictured on screen, and sometimes bear little clear relationship with what the camera captures. An example of this can be found when Keiller provides an extreme close-up shot of the anthropomorphically-shaped mouth of a red post box, over which Redgrave's narrator tells Robinson's story thus: 'Of course Robinson wasn't his real name, and he wasn't English. He had arrived in London in 1966 from Berlin, before which his history was uncertain, having been attracted by the period's popular culture and the presence of so many prehistoric structures in the landscape.' As this sentence draws to a close, Keiller cuts to another image of the post box, this time captured in long shot, showing its precise topographical location on the corner of Broad Street in Oxford. A discernable spatial tension develops here between the image of this English location onscreen and the image evoked by the narrator off-screen, of Robinson elsewhere, in Berlin. At the same time, as these words are spoken, we can also imagine the body of Redgrave (the individual, the actress and the star) performing the narration in a sound studio. So this particular sequence conjures up a complex and elastic phonotope in which disparate events and locations contrast and fold into one another. 
But on a number of other occasions the relationship between the words and images more clearly correlate (as is often, of course, the case in documentary films), such as in the sequence in which we see shots of a Lidl supermarket while the voice remarks that this company has been accused of mistreating its employees. Similarly, shots of Harrowdown Hill are provided when the voice speaks of the suicide of or the weapons expert Dr David Kelly, and images of RAF Brize Norton are on screen when military activities are spoken of. Here, then, the voice temporarily adopts a seemingly more straightforward and unproblematic, expository tone. But as it exists within the contexts of the previous, more playful and ironic performances of lines in the film, even this sequence ultimately resists interpretation as an example of the communication of documentary fact, and it thus serves further to facilitate an 'opening up' of the places depicted in the film in spatial terms. Overall, then, the shifting mode of vocal address in the film - moving quickly between hesitancy to knowing irony to authority - effectively lends Redgrave's voice a fluid sense of enunciation. In its constant shifting between describing and departing from the image, and in its shifts is performative style, the voice assumes an open, unlocated, or 'unenclosed' status. As such, Redgrave's voice-over serves as an aesthetic strategy that suitably evokes the radical vision of spatiality at the heart of the film.

\section{The voice-over and a progressive sense of place}

It is significant that Robinson in Ruins was an outcome of a collaborative research project entitled 'The Future of Landscape and the Moving Image' involving Keiller, the geographer Doreen Massey, and the author and academic Patrick Wright, as the film - and the research project - were profoundly influenced by Massey's concept of a progressive, global sense of place. In her theoretical engagement with what she sees as a 'new phase of internationalization', Massey has sought to understand how, 'in the face of all this movement and intermixing, can we retain any sense of a local place and it particularity?' (Massey 1994: 146) The key aim of her work, then, has been to answer questions such as: 'Can we rethink our sense of place? Is it not possible for a sense of place to be progressive; not self-enclosing and defensive, but outward-looking?' (Massey 1994: 147) In conceptualising such a new, progressive sense of place in the contemporary world, Massey has argued that instead of thinking about places as enclosed, or as areas defined by boundaries, 'they can be imagined as articulated moments in networks of social relations and understandings'. (Massey 
1994: 154) In For Space (2005), Massey asks: 'What if we open up the imagination of the single narrative to give space (literally) for a multiplicity of trajectories?'(Massey 2005: 5) Thus, in its simultaneous temporality, space for Massey is always in a process of 'becoming', of being made. This notion is developed in her online essay accompanying Robinson in Ruins:

If the instantaneous moment were not itself imbued with temporality there could be no temporal trajectory.

Correspondingly, for time/temporality/becoming to exist, space has to be imbued with the temporal. As a slice through time, space is a dynamic simultaneity and that is quite different from a stasis. We must, then, re-write Bergson's dictum. Rather than 'we cannot make time out of space', it is that for there to be time, space must itself be imbued with temporality. Space as a simultaneity indeed, but a cut through ongoing histories. Not a surface but a simultaneity of stories-so-far. (Massey 2011)

In their research for Robinson in Ruins, Massey and Keiller evidently shared an ambition to evoke a spatio-temporal sense of 'becoming' that might counter the effects of material and imaginative enclosure: 'We see the landscape differently: not closed down into a familiar satisfaction but opened up to reinterpretation.' (Massey 2011) In its challenge to enclosure and the human displacement that it subsequently generates, Robinson in Ruins successfully evokes a sense of 'becoming' in space, an uncovering of 'stories-so-far', thereby seeking to create a progressive sense of place in which a sense of 'becoming' (or at least a recognition of what this process might entail) might be facilitated. To do this, Redgrave's voice-over evokes places and landscapes vividly 'alive with temporalities.' (Massey 2011)

It should be mentioned here that there are sections in the film when Redgrave's voice remains silent. And it is significant to note that Massey argues elsewhere in her essay 'Landscape/space/politics' that the spatio-temporal 'becoming' communicated in the film is also evident in Keiller's long takes of the rhythms of nature at work:

The camera stays on the butterflies working the teasel for four minutes and 15 seconds. There are many such passages in this film. The camera while filming does not travel. And often, with the 
cowslips, say, or the marsh marigolds (with ducks), the rose and the bee, the white foxglove, and the butterflies with the teasel, there is not much movement in the image either. Certainly there is no movement in the sense of 'mobility and displacement' which is one aspect of what this project was supposed to be about.

But these long takes are not about stasis either. Stuff is happening. The plants are getting on with their business. The bees and the butterflies are working them. The air is busy with activity. (Massey 2011)

Massey also argues that these long takes of flowers and plants give us, 'in the midst of the rush and flow of globalisation, a certain stillness. But they are not stills. They are about duration. They tell us of 'becoming', in place.' (Massey 2011) These long, held shots of the teasels and butterflies in the film which seem to suggest panglobal rhythms of life are not governed by neoliberalism (or at least ways of comprehending places in such a way that frees them from imaginative enclosure), Redgrave's voice similarly opens up the imagination to a radically temporal spatiality that is resistant to dominant modes of understanding space and place.

\section{Conclusion}

Patrick Keiller's film Robinson in Ruins suggests radical new ways of engaging with, imagining and understanding places in southern England through processes of history and memory, but also through poetic creativity, at a time when it appears that this landscape is increasingly being placed in the service of neoliberal capitalism and the concomitant forces of the State and its allies. The film's success primarily lies in the way in which its excavation of the history of enclosure in specific contemporary places in this English landscape is put into the service of providing a powerful critique of the contemporary material and imaginative enclosure of land, and, at the same time, how the aesthetic strategy of a scripted, ironic voice-over from a fictional female character is shown to be potentially suggestive of a radical, progressive vision of place that might resist such enclosure. At the heart of the film's radicalism is Doreen Massey's notion of spatial 'becoming', which operates as an attempt to spatially counter such historical and socio-cultural trends and their effects of the everyday life of places. In order to successfully communicate these ideas the film 
constructs, through Redgrave's voice-over performance, a rich, boundless, uncontainable phonotope; a 'voice-space' which temporally informs and structures the spatial imaginary and, as it does this, transcends material, 'real' spaces represented by the images captured by Keiller's camera. This phonotope, operating alongside and against the long sections featuring the slow rhythms of nature at work, aptly suggests, in aesthetic terms, the 'multiplicity of trajectories' that Massey calls for in her spatial theory, thereby invoking a radical new spatial practice, or 'becoming', through film sound. To paraphrase Massey once more, this phonotope is where the 'multiplicity' of stories about the contemporary landscape really comes alive in the film.

I want to end this chapter by remarking that while I was thinking about Redgrave's performance in Robinson in Ruins, and another performance, as Mrs Dalloway in the 1997 film directed by Marleen Gorris, I was reminded of a section of Virginia Woolf's 1925 novel. In a memorable passage, an old woman, located opposite the Regent's Park Tube station, sings an ancient song that celebrates life, endurance, and continuity. She is oblivious to everyone around her as she sings, and is beyond caring what the world thinks. The narrator in the novel explains that no matter what happens in the world, the old woman will still be there, even in 'ten million years' and that the song has soaked 'through the knotted roots of infinite ages.' (Woolf 2012: 65) Roots, intertwined and hidden beneath the earth, suggest here the deepest parts of people's souls, and this woman's song touches everyone who hears it in some way. It is tempting to read Redgrave's voice in Robinson in Ruins as a similar type of sonic force; as a fluidly free, spatial phenomenon that also soaks through the 'knotted roots' of space and time, and, as such, that connects us with freed landscapes of the present and the past. It is a voice that allows us to comprehend place, not in terms of 'belonging', but instead in terms of 'becoming'.

\section{Sources}

Altman, Rick (1992), 'Afterword: A Baker's Dozen Terms for Sound Analysis.' In Sound Theory, Sound Practice, edited by Rick Altman, London and New York: Routledge, pp. 249-253. 
Attenborough, Richard, Oh! What a Lovely War (1969), film UK: Paramount Pictures.

Bakhtin, Mikhail M. (1981), The Dialogic Imagination: Four Essays, ed. Michael Holquist, tr. Caryl Emerson and Michael Holquist. Austin and London: University of Texas Press.

Barthes, Roland (1977), 'The Grain of the Voice', Image Music Text, London: Fontana.

Barwell, Claire (1997), 'Interview with Patrick Keiller', Pix, 2, pp. 160-165.

Bruzzi, Stella (2000), New Documentary: A Critical Introduction, London and New York: Routledge.

Chanan, Michael (2007), The Politics of Documentary, London: British Film Institute.

Chion, Michel (1994) [1990], Audio-Vision: Sound on Screen, trans. Claudia Gorbmann, New York: Columbia University Press.

Chion, Michel (1999), The Voice in Cinema, trans. Claudia Gorbmann, New York: Columbia University Press.

Dave, Paul (2000), 'Representations of Capitalism, History and Nation in the Work of Patrick Keiller'. In British Cinema, Past and Present, edited by Justine Ashby and Andrew Higson, London: Routledge, pp. 339-351.

Dave, Paul (2011), 'Robinson in Ruins: New materialism and the archaeological imagination', Radical Philosophy, 189, pp. 19-35.

Doane, Mary Ann (1980), 'The Voice in the Cinema: the articulation of body and space', Yale French Studies, 60, Cinema/Sound, pp. 33-50.

Fisher, Mark (2010), 'English Pastoral', Sight and Sound, 20:11, pp. 22-24.

Fowkes, Katherine A. (1998), Giving Up the Ghost: Spirits, Ghosts, and Angels in Mainstream Comedy Films, Detroit: Wayne State University Press.

Gorris, Marleen, Mrs Dalloway (1997), film UK: Artificial Eye. 
Ivory, James, Howard's End (1992), film UK: Merchant Ivory Productions.

Keiller, Patrick (1994), 'The Visible Surface', Sight and Sound, 4: 11, p. 35.

Keiller, Patrick (1994), London, film UK: British Film Institute.

Keiller, Patrick (1997), Robinson in Space, film UK: British Broadcasting Corporation.

Keiller, Patrick (2009), 'The Future of Landscape and the Moving Image'. http://.thefutureoflandscape.wordpress.com/ [Accessed 5 March 2012]

Keiller, Patrick (2010), Robinson in Ruins, film UK: British Film Institute.

Keiller, Patrick (2012), The Possibility of Life's Survival on the Planet, London: Tate Publishing.

Kozloff, Sarah (1989), Invisible Storytellers: Voice-over Narration in American Fiction Film, Berkeley, Los Angeles and London: University of California Press.

Lawrence, Amy (1991), Echo and Narcissus: Women's Voices in Classical

Hollywood Cinema, Berkeley and Los Angeles: University of California Press.

Logan, Joshua, Camelot (1967), film US: Warner Bros.

Maasø, Arnt (2008), 'The Proxemics of the Mediated Voice.' In Lowering the Boom:

Critical Studies in Film Sound, edited by Jay Beck and Tony Grajeda, Urbana and Chicago: University of Illinois Press, pp. 36-50.

Martin-Jones, David (2002), 'Patrick Keiller', Journal of Popular British Cinema, 5, pp. 123-132.

Massey, Doreen (1994), Space, Place and Gender, Cambridge: Polity Press, 1994.

Massey, Doreen (2005), For Space, London: Sage.

Massey, Doreen (2011), 'Landscape/space/politics: an essay'. http://thefutureoflandscape.wordpress.com/landscapespacepolitics-an-essay/ [Accessed 5 March 2015] 
Nichols, Bill (1988), 'The voice of documentary'. In New Challenges for

Documentary, edited by Alan Rosenthal, Berkeley and Los Angeles: University of

California Press. pp. 48-63.

Ophüls, Max (1948), Letter from an Unknown Woman, film US: Universal Studios Plantinga, Carl (1997), Rhetoric and Representation in Nonfiction Film. Cambridge:

Cambridge University Press.

Powrie, Phil (2000), 'On the Threshold Between Past and Present: 'Alternative heritage', in British Cinema, Past and Present, edited by Justine Ashby and Andrew Higson, London and New York: Routledge, pp. 316-326.

Sennett, Richard (1990), The Conscience of the Eye, New York: Alfred A. Knopf.

Silverman, Kaja (1988), The Acoustic Mirror: The Female Voice in Psychoanalysis and Cinema, Bloomington: Indiana University Press.

Sinclair, Iain (1994), 'London: Necropolis of Fretful Ghosts', Sight and Sound, 4: 6 (June) pp. 12-15.

Sjogren, Britta (2006), Into the Vortex: Female Voice and Paradox in Film, Chicago: University of Illinois Press.

Smethurst, Paul (2000), The Postmodern Chronotope: Reading Space and Time in Contemporary Fiction, Amsterdam and Atlanta: Rodopi.

Smith, Claire (2000), 'Travelling Light: New Art Cinema in the 90s'. In British Cinema of the 90s, edited by Robert Murphy, London: British Film Institute, pp. 145155.

Smith, Jacob (2008), Vocal Tracks: Performance and Sound Media, Berkeley and Los Angeles: University of California Press.

Stam, Robert (1989), Subversive Pleasures: Bakhtin, Cultural Criticism, and Film, Baltimore: John Hopkins University Press.

Tsaliki, Liza, Christos A. Frangonikolopoulos, Asteris Huliaras (2011), Transnational 
Celebrity Activism in Global Politics: Changing the World? Bristol: Intellect.

Wojcik, Pamela Robertson (2006), 'The Sound of Film Acting', in Journal of Film and Video, 58,1/2, pp. 71-83.

Woolf, Virginia (2012) [1925], Mrs Dalloway, London: Urban Romantics.

Zinnemann, Fred (1966), A Man for All Seasons, film UK, Columbia Pictures.

Paul Newland is Reader in Film Studies at Aberystwyth University. He is author of British Films of the 1970s (MUP, 2013) and The Cultural Construction of London's East End (Rodopi, 2008), and editor of British Rural Landscapes on Film (MUP, 2016) and Don't Look Now: British Cinema in the 1970s (Intellect, 2010). He has published widely on constructions of space and place in film.

Dr Paul Newland

Department of Theatre, Film and Television Studies

Aberystwyth University

Parry Williams Building

Penglais Campus

Aberystwyth

SY23 3AJ

Tel: 01970622952

email pnn@aber.ac.uk 
${ }^{1}$ Michel Chion developed the notion of the acousmetre, which he described as vocalphantoms of not-yet-embodied voices See Michel Chion, The Voice in Cinema (New York: Columbia University Press, 1999): p. 21. See also Mary Ann Doane on disembodied voices in 'The Voice in the Cinema: the articulation of body and space', in Yale French Studies, 60, Cinema/Sound (1980): p.42.

${ }^{2}$ See Richard Sennett, The Conscience of the Eye (New York: Alfred A. Knopf, 1990): pp. 191-192; Paul Smethurst, The Postmodern Chronotope: Reading Space and Time in Contemporary Fiction (Amsterdam and Atlanta: Rodopi, 2000): p. 12.

${ }^{3}$ See Rick Altman, 'Afterword: A Baker's Dozen Terms for Sound Analysis', in Sound Theory, Sound Practice, edited by Rick Altman (London and New York: Routledge, 1992): p. 252.

${ }^{4}$ While perhaps Robinson in Ruins might not the best example of a film that develops spatiality out of microphone placement, it is worth noting that Maasø draws on Edward T. Hall's work on proxemics (the importance of spatial proximity between subjects in communication) to analyse the function of microphone placement, perspective, vocal distance and intended earshot in film dialogue. See Arnt Maasø, 'The Proxemics of the Mediated Voice.' In Lowering the Boom: Critical Studies in Film Sound, edited by Jay Beck and Tony Grajeda (Urbana and Chicago: University of Illinois Press, 2008): pp. 36-50.

${ }^{5}$ For work on 'voice-offs', see Mary Ann Doane, 'The Voice in the Cinema: The Articulation of Body and Space', Yale French Studies, no. 60 (1980).

${ }^{6}$ Redgrave's career in the US has suffered due to her outspoken comments in support of the Palestine Liberation Organization (PLO). See Liza Tsaliki, Christos A. Frangonikolopoulos, Asteris Huliaras, Transnational Celebrity Activism in Global Politics: Changing the World? (Bristol: Intellect, 2011), p. 218. 


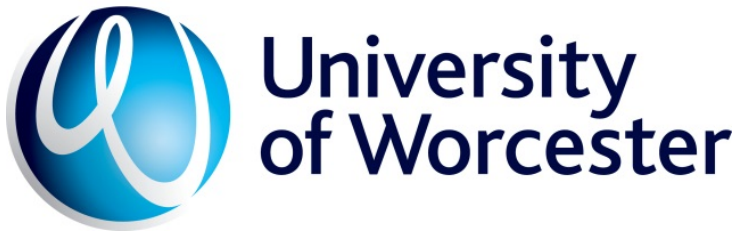

Original citation: Newland, Paul (2016) The Spatial Politics of the Voice in Patrick Keiller's Robinson in Ruins (2010). The New Soundtrack, 6 (2). pp. 129-142. ISSN Print: 2042-8855 Online: 2042-8863

Permanent WRaP URL: https://eprints.worc.ac.uk/id/eprint/9220

\section{Copyright and reuse:}

The Worcester Research and Publications (WRaP) makes this work available open access under the following conditions. Copyright $\odot$ and all moral rights to the version of the paper presented here belong to the individual author(s) and/or other copyright owners. To the extent reasonable and practicable the material made available in WRaP has been checked for eligibility before being made available.

Copies of full items can be used for personal research or study, educational, or not-for-profit purposes without prior permission or charge, provided that the authors, title and full bibliographic details are credited, a hyperlink and/or URL is given for the original metadata page and the content is not changed in any way.

Publisher's statement: This is an Accepted Manuscript of an article published by Edinburgh University Press in The New Soundtrack, available online: https://www.euppublishing.com/doi/10.3366/sound.2016.0087

\section{A note on versions:}

The version presented here may differ from the published version or, version of record, if you wish to cite this item you are advised to consult the publisher's version. Please see the 'permanent WRaP URL' above for details on accessing the published version and note that access may require a subscription.

For more information, please contact wrapteam@worc.ac.uk 